\title{
An empirical test of the 'shark nursery area concept' in Texas bays using a long-term fisheries-independent data set
}

\author{
John T. Froeschke ${ }^{1,4, *}$, Gregory W. Stunz ${ }^{1}$, Blair Sterba-Boatwright ${ }^{2}$, \\ Mark L. Wildhaber ${ }^{3}$ \\ ${ }^{1}$ Harte Research Institute for Gulf of Mexico Studies and Department of Life Sciences, \\ Texas A\&M University - Corpus Christi, 6300 Ocean Drive, Corpus Christi, Texas 78412, USA \\ ${ }^{2}$ Department of Mathematics and Statistics, Texas A\&M University - Corpus Christi, 6300 Ocean Drive, Corpus Christi, \\ Texas 78412, USA \\ ${ }^{3}$ Columbia Environmental Research Center, U.S. Geological Survey, 4200 New Haven Road, Columbia, Missouri 65201, USA \\ ${ }^{4}$ Present address: Gulf of Mexico Fishery Management Council, 2203 N. Lois Ave., Suite 1100, Tampa, Florida 33607, USA
}

\begin{abstract}
Using a long-term fisheries-independent data set, we tested the 'shark nursery area concept' proposed by Heupel et al. (2007) with the suggested working assumptions that a shark nursery habitat would: (1) have an abundance of immature sharks greater than the mean abundance across all habitats where they occur; (2) be used by sharks repeatedly through time (years); and (3) see immature sharks remaining within the habitat for extended periods of time. We tested this concept using young-of-the-year (age 0) and juvenile (age 1+ yr) bull sharks Carcharhinus leucas from gill-net surveys conducted in Texas bays from 1976 to 2006 to estimate the potential nursery function of 9 coastal bays. Of the 9 bay systems considered as potential nursery habitat, only Matagorda Bay satisfied all 3 criteria for young-of-the-year bull sharks. Both Matagorda and San Antonio Bays met the criteria for juvenile bull sharks. Through these analyses we examined the utility of this approach for characterizing nursery areas and we also describe some practical considerations, such as the influence of the temporal or spatial scales considered when applying the nursery role concept to shark populations.
\end{abstract}

KEY WORDS: Bull shark · Nursery · Essential Fish Habitat · Gulf of Mexico

\section{INTRODUCTION}

Coastal estuaries and bay systems have been recognized as important nursery habitats for many aquatic species, including sharks. The shallow waters of the Gulf of Mexico support a diverse and abundant shark assemblage and provide nursery habitat for several shark species (Hueter \& Tyminski 2007, McCandless et al. 2007, Neer et al. 2007, Parsons \& Hoffmayer 2007). Froeschke et al. (2010) found that the bull shark Carcharhinus leucas was the most abundant coastal shark in Texas bays, and this species is known to use shallow coastal regions as young-of-the-year (YOY) or juvenile habitat (Simpfendorfer et al. 2005, Neer et al. 2007, Heupel \& Simpfendorfer 2008, Ortega et al. 2009). Hueter \& Tyminski (2007), in their study on temporal and distributional patterns of juvenile sharks off Florida and Texas, found that the blacktip shark C. limbatus was the most abundant species. However, other gear types (hook-and-line), were used, and the study included coastal and offshore structures, possibly explaining the difference between the 2 studies in spe- 
cies composition. In Heuter \& Tyminski (2007) juveniles from 12 shark species were captured off Texas, suggesting that several species use coastal habitats within the Gulf of Mexico as nurseries. Currently, bays along the entire Texas coast are considered nursery habitat for bull sharks, but this viewpoint is based only on the presence of juveniles within these (or similar) areas (McCandless et al. 2002, 2007, Hueter \& Tyminski 2007). Froeschke et al. (2010) developed a longterm fisheries-independent shark catch data set to examine coastal shark habitat value in Texas bays based on environmental conditions for bull, blacktip, and bonnethead Sphyrna tiburo sharks. They found that habitat value varies greatly among bays in this region, and shark distribution patterns were closely linked to salinity, temperature, and proximity to inlets along the Gulf of Mexico. Bull shark was the most abundant shark species, and most individuals captured were juveniles (based on length), suggesting that portions, but unlikely all, of the Texas coast represents nursery habitat for this species.

Nursery habitat for aquatic species has been broadly defined as habitats that contribute disproportionately to the adult population in comparison to other habitats in which the species occurs (Beck et al. 2001). The use of the term 'shark nursery habitat' has varied widely in the literature, with some nurseries having been identified based only on the presence of a few juvenile sharks (McCandless et al. 2007). This 'general occurrence' approach potentially identifies all coastal habitats as essential, restricting the ability to prioritize areas for conservation and management (Levin \& Stunz 2005). Moreover, not all habitats occupied by juveniles should be considered nursery habitat (Driggers et al. 2008). To address this problem, Heupel et al. (2007) outlined a more tractable concept for the identification of shark nursery habitat by obtaining information on abundance, residency, and temporal patterns of sharks within potential nursery habitats. To identify shark nursery habitat, several criteria must be met: (1) the abundance of juvenile sharks in a specific habitat is greater than the mean abundance in all habitats where juveniles occur; (2) juvenile sharks must use the habitats repeatedly through time (years); and (3) juvenile sharks must remain within the habitat for extended periods of time.

In the present study we evaluated bull shark temporal and spatial distribution patterns within 9 major bays along the entire Texas coast from 1976 to 2006 using the shark nursery concept outlined by Heupel et al. (2007). We describe nursery habitat for an important apex predator and discuss some practical limitations of empirically applying this concept, to help improve management and delineation of Essential Fish Habitat (EFH) for sharks (Levin \& Stunz 2005).

\section{MATERIALS AND METHODS}

Study area. The present study was conducted in 9 major bay systems along the Texas coast in the northwestern Gulf of Mexico from 1975 to 2006 (Fig. 1). Barrier islands separate these bays from the Gulf of Mexico along the majority of the coastline, and saltwater exchange occurs via 6 major tidal inlets. Texas bays are shallow subtropical estuaries that are physically dynamic, and most are located near large human population centers. This region supports a variety of habitat types (e.g. seagrass meadows, oyster reefs, marsh, non-vegetated bottom) and provides nursery habitat for many teleost and invertebrate species (Reese et al. 2008, Stunz et al. 2010).

Field collections. Bull shark catch data were obtained from the coast-wide gill-net survey conducted by the Texas Parks and Wildlife Department that was established in Texas bay systems in 1975 and continued through at least 2010. For the present study, data included samples from 1976 to 2006. Coastal fisheries resource monitoring data were collected as a stratified cluster sampling design; each bay system serves as non-overlapping strata with a fixed number of samples $\left(\mathrm{n}=45\right.$ bay $^{-1}$ season $\left.^{-1}\right)$. Gill-nets were deployed each spring (April, May, June) and fall (September, October, November; Martinez-Andrade et al. 2009). Sample locations were drawn independently and without replacement for each season (MartinezAndrade et al. 2009). Bull sharks were sampled using standardized $183 \mathrm{~m}$ gill-nets perpendicular to shore. Nets were constructed of 4 panels with stretched mesh sizes of $76,102,127$, and $152 \mathrm{~mm}$. Gill-nets were deployed $1 \mathrm{~h}$ before sunset, fished overnight, and retrieved within $4 \mathrm{~h}$ of sunrise the following day, and a total set time was calculated for each sample. Each captured shark was identified to species, measured, and released. Abundance data were converted to catch per unit effort (CPUE) by dividing the number of bull sharks captured by 'soak time', in hours, of each net in the sample.

The present study focused on identification of both YOY (i.e. age 0) and juvenile (i.e. age 1+ yr) nursery habitat. Age class of sharks was estimated from total length (TL) using published length-at-age estimates (Branstetter \& Stiles 1987, Neer et al. 2005). A wide range in size at birth of bull sharks has been reported (Neer et al. 2005), between 633 and 839 mm TL (Clark \& von Schmidt 1965), with growth rates of 150 to 200 $\mathrm{mm} \mathrm{yr}^{-1}$ (Branstetter \& Stiles 1987). For the present study, bull sharks $<900 \mathrm{~mm}$ TL were considered YOY and used to identify YOY nursery habitat. Sharks between 900 and $1600 \mathrm{~mm}$ TL were considered immature (hereinafter referred to as 'juvenile[s]') and used to identify juvenile nursery habitat. 


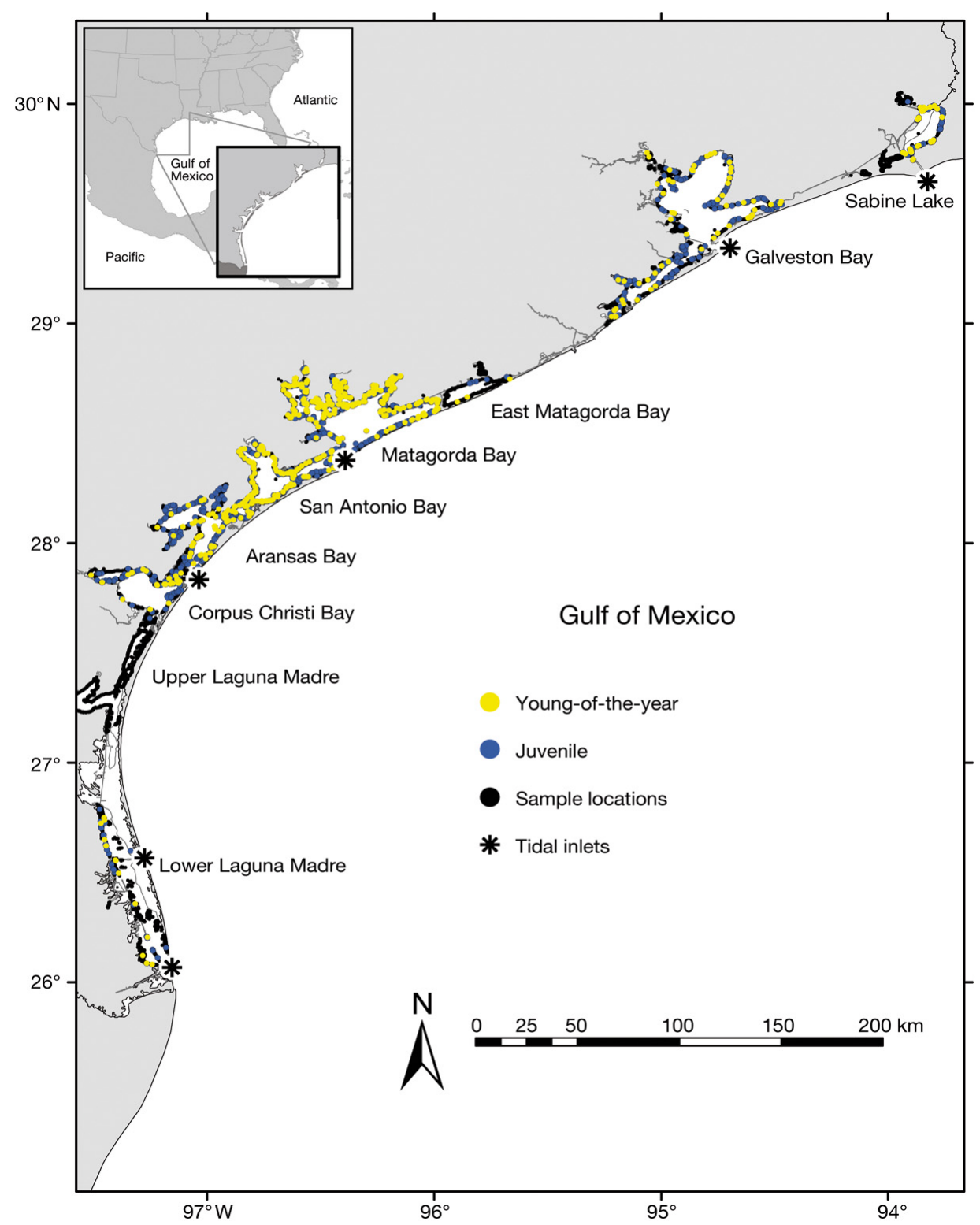

Fig. 1. Carcharhinus leucas. Coastal shark gill net survey locations $(\mathrm{n}=19709)$ from 1976 to 2006 in Texas. Capture locations of young-of-the-year $(\odot)$ and juvenile $(\bullet)$ bull sharks, and locations sampled but with no bull sharks captured $(\bullet)$ are indicated. Bays are connected to the Gulf of Mexico through 6 tidal inlets (*), from north to south: Sabine Pass, Galveston Pass, Matagorda ship channel, Aransas Pass, Mansfield Pass, and Brazos Santiago Pass

Shark nursery area concept. Statistical analysis: Delineation of nursery areas was based on the criteria of Heupel et al. (2007) and was tested using weighted leastsquares regression to simultaneously determine spatial and temporal patterns of shark abundance within each bay system. Prior to analyses, shark CPUE data from the 45 nets season ${ }^{-1}$ bay $^{-1}$ were aggregated into a single mean value per season per bay. Seasonal data were subsequently aggregated into an annual mean value per bay system to stabilize variance and to remove excess zeros from the matrix (Pondella et al. 2008). Upper Laguna Madre was excluded from the analysis as no bull sharks were captured in this bay during the $30 \mathrm{yr}$ study. YOY and juvenile bull shark catch data were analyzed separately to assess ontogenetic shifts in nursery use patterns. Preliminary analyses of bull shark CPUE indicated that despite improvement through $\log _{10}$ transformation, model residuals were not normally distributed, variance differed among bays, and residuals were temporally autocorrelated. Weighted least squares with restricted maximum likelihood estimation (REML) was used with the following model:

$$
y_{i j}=a_{i}+b_{j}+a b_{i j}+\varepsilon_{i j}
$$


where $y_{i j}$ is $\log _{10}$ CPUE for bay $i$ in year $j_{i} a_{i}$ is the effect of bay $i, i=1, \ldots 8 ; b_{j}$ is the effect of year $j_{1} j=1976 \ldots$ $2006 ; a b_{i j}$ is the interaction effect of bay with year; and $\varepsilon_{i j}$ is the residual for bay $i$ in year $j$.

In addition, because of autocorrelation effects from year to year, the residuals $\varepsilon_{i j}$ from the model above were given a first-order autoregressive (AR1) structure; that is,

$$
\begin{aligned}
& \varepsilon_{i j}(j+1)=\rho \varepsilon_{i j}+\eta_{i j} \\
& \eta_{i j} \sim \operatorname{Normal}\left(0, \sigma_{i}^{2}\right)
\end{aligned}
$$

That is, the time series for each bay has the same autocorrelation $\rho$, and the residuals $\eta_{i j}$ from the AR1 process are normal with mean 0 and different variances $\sigma_{i}^{2}$ permitted for each bay $i$. We used Akaike's information criterion (AIC) and a log-likelihood ratio test to determine whether the more complex variance and/or error structures were warranted. Nonparametric bootstrapping with replacement $(n=1000)$ was used to estimate confidence intervals (CIs) of model parameters without making assumptions about the population distribution (Efron \& Tibshirani 1993). We considered all analyses significant at $\alpha=0.05$. Analyses were carried out in R 2.71 (R Development Core Team 2008) with functions from the 'mgcv' (Wood 2008), 'nlme' (Pinheiro et al. 2008), and 'sm' packages (Bowman \& Azzalini 1997).

Criterion 1: A central assumption of shark nurseries is that sharks are significantly more abundant in nurseries than other areas. On the Texas coast, the 9 major bay systems (Fig. 1) encompass potential shark nursery habitat. We tested the nursery area concept criterion that juvenile bull shark abundance was significantly higher in nurseries than surrounding areas by extending the weighted least-squares model with non-parametric bootstrapping. The aggregated data were re-sampled using bootstrapping with replacement $(n=1000)$. For each bootstrap iteration, annual mean bull shark CPUE was determined for each bay and areas with CPUE above the population mean for the entire study period (i.e. satisfying Criterion 1) were coded as ' 1 ', otherwise it was coded as '0.' Using this approach, we were able to test Criterion 1 using the probability that mean CPUE of an individual bay was not significantly different from the population mean. This analysis was completed separately for both YOY and juvenile bull sharks.

Criterion 2: A second requirement of shark nurseries is that young sharks must use the bay repeatedly through time (i.e. temporal stability). This criterion was also tested using the generalized least-squares model testing that the overall slope (temporal effect) was not significantly less than zero (i.e. $\log _{10}$ CPUE was stable or increasing throughout the study period). Temporal stability was examined both for the entire study popu- lation (all bays) and individually for bays satisfying Criterion 1. CPUE slopes and 95\% CIs were estimated using bootstrapping. Slope estimates for individual bays that were positive or contained 0 within their CI were considered to have satisfied Criterion 2.

Criterion 3: The final assumption of shark nursery habitat is that sharks must remain within the habitat for extended periods of time. We could not examine movement patterns of individual sharks within study sites, but it was possible to infer residency patterns of YOY bull shark 'cohorts.' For example, bull sharks are typically born in spring or early summer at $\sim 650 \mathrm{~mm}$ TL (Neer et al. 2005) and grow 100 to $200 \mathrm{~mm} \mathrm{yr}^{-1}$. For YOY nursery areas, examination of size-frequency distributions of YOY sharks in putative nursery areas between spring and fall sampling should reflect a positive shift in mean size due to growth of the cohorts if individuals are remaining within the study area between spring and fall. We developed length-frequency histograms by season for the entire population (all bays pooled) and for bays that satisfied Criteria 1 and 2 to test the hypothesis that the TL of individuals is significantly longer in fall as compared to spring sampling with non-parametric bootstrap test for equality ( $\mathrm{n}=1000$; Bowman \& Azzalini 1997).

For juveniles (i.e. $>900 \mathrm{~mm}$ TL) we assessed residency patterns by examining length-frequency distributions and autocorrelation of catch patterns between consecutive years. The juvenile age class comprised fishes from age 1 yr to at least $10 \mathrm{yr}$ based on length-atage estimates; therefore, it was not possible to discern individual cohorts. As a result, we expected similar size distribution patterns between seasons as well as repeated use of bays over years. We tested the hypothesis that TL is not significantly different between seasons with non-parametric bootstrapping (as described above). We evaluated repeated use through time by determining autocorrelation of CPUE patterns between years and testing the significance of including the AR1 function in the error term of the weighted least-squares model using the log-likelihood test.

\section{RESULTS}

Bull sharks were sampled in 9 bays along the entire Texas coast from 1976 to 2006, and 5666 individuals were captured. Mean TL of captured individuals used in the present study was $1024 \mathrm{~mm}$ TL and ranged from 550 to $2071 \mathrm{~mm}$ TL, indicating that the shark assemblage was dominated by immature animals (Fig. 2A). Abundance of bull sharks varied widely among the 9 bays. Overall, CPUE for both YOY and juvenile bull sharks were highest along the central Texas coast (i.e. Matagorda and San Antonio Bays), moderate in northern bays, and low in southern lagoon systems (Fig. 1). 

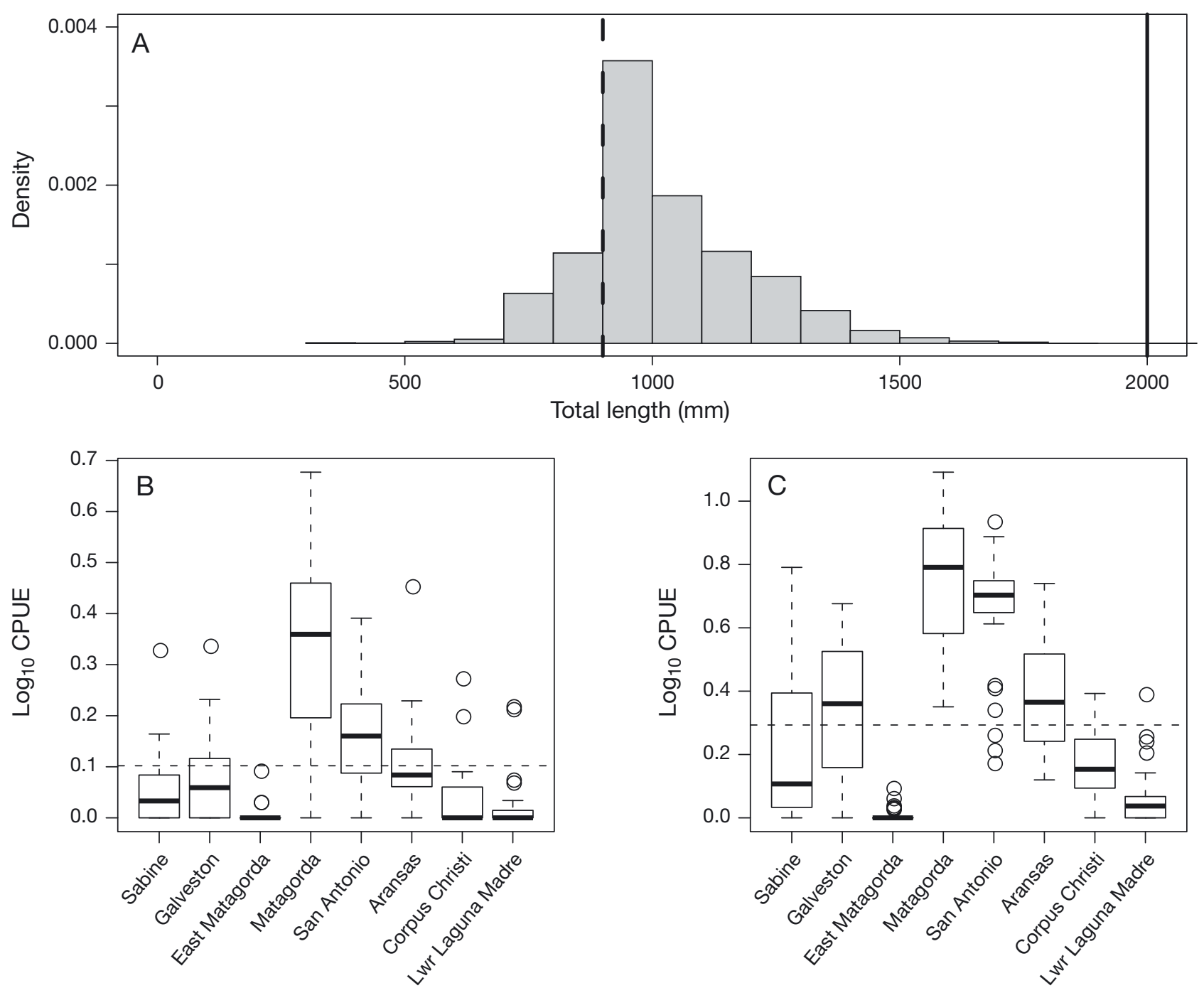

Fig. 2. Carcharhinus leucas. (A) Histogram of length at capture from 1976 to 2006 in Texas. Size at maturity (solid vertical line) and estimated upper size limit of age 0 (young-of-the-year; YOY) sharks (dashed vertical line) based on previous length-at-age studies $(n=5639)$ are indicated. Box-and-whisker plot of (B) YOY and (C) juvenile $\log _{10}$ catch-per-unit-effort $\left(C P U E ;\right.$ sharks $\left.h^{-1}\right)$. The horizontal line within each box is the median, and lower and upper boundaries of the boxes indicate the 25th and 75th percentiles. Whiskers below and above the boxes indicate the 5th and 95th percentiles. O: outlying points. Horizontal dashed line: the mean population $\log _{10}$ CPUE over the entire study period. Lwr: Lower

\section{YOY bull sharks}

\section{Criterion 1 (spatial patterns)}

Testing the central assumption of shark nursery habitat i.e. that the abundance of YOY bull sharks in a specific bay is greater than the mean abundance in all Texas bays where YOY bull sharks occur, spatial patterns were examined using weighted least-squares regression where each bay was included as a covariate in the model (Table 1A). For all 8 bays where sharks were captured, the mean population $\log _{10}$ CPUE was 0.102 (Fig. 2B). Only Matagorda and San Antonio Bays had a mean CPUE above the population mean for the entire study period (Fig. 2B). However, only Matagorda Bay's CPUE was significantly above the population mean $(p<0.001$; Table 2A).

\section{Criterion 2 (temporal patterns)}

The criterion that YOY sharks use Texas bays repeatedly through time (temporal stability) was tested. For the entire population, mean CPUE increased slightly throughout the study period, although a significant trend was not detected ( $p>0.10$; Table 1A), indicating stability of the population (Fig. 3A). Temporal patterns were also examined individually by bay system (Fig. 3B-I) 
Table 1. Carcharhinus leucas. Parameter estimates from weighted least-squares model for (A) young-of-the-year $(n=1053)$ and $(B)$ juvenile $(n=4586)$ bull sharks. Bull sharks were sampled in 9 bays along the entire Texas coast from 1976 to 2006. However, Upper Laguna Madre was excluded from analyses as no bulls sharks were captured during the study period

\begin{tabular}{|c|c|c|c|c|}
\hline Coefficient & Value & SE & $t$ & $\mathrm{p}$ \\
\hline \multicolumn{5}{|l|}{ A Young-of-the-year } \\
\hline Year & 0.01 & 0.00 & 1.5 & $>0.10$ \\
\hline Sabine & -12.80 & 8.31 & -1.5 & $>0.10$ \\
\hline Galveston & -13.23 & 4.69 & -2.8 & 0.01 \\
\hline East Matagorda & 0.16 & 4.69 & $<0.1$ & $>0.10$ \\
\hline Matagorda & 3.44 & 4.69 & 0.7 & $>0.10$ \\
\hline San Antonio & -5.97 & 4.69 & -1.3 & $>0.10$ \\
\hline Aransas & -2.94 & 4.69 & -0.6 & $>0.10$ \\
\hline Corpus Christi & -1.37 & 4.69 & -0.3 & $>0.10$ \\
\hline Lower Laguna Madre & 1.13 & 4.69 & 0.2 & $>0.10$ \\
\hline Year × Galveston & $<0.01$ & 0.01 & 0.1 & $>0.10$ \\
\hline Year $\times$ East Matagorda & -0.01 & 0.01 & -1.4 & $>0.10$ \\
\hline Year $\times$ Matagorda & -0.01 & 0.01 & -1.7 & 0.10 \\
\hline Year $\times$ San Antonio & $<0.01$ & 0.01 & -0.7 & $>0.10$ \\
\hline Year $\times$ Aransas & -0.01 & 0.01 & -1.0 & $>0.10$ \\
\hline Year $\times$ Corpus Christi & -0.01 & 0.01 & -1.2 & $>0.10$ \\
\hline $\begin{array}{l}\text { Year } \times \text { Lower Laguna } \\
\text { Madre }\end{array}$ & -0.01 & 0.01 & -1.5 & $>0.10$ \\
\hline \multicolumn{5}{|l|}{ B Juvenile } \\
\hline Year & 0.03 & 0.01 & 3.3 & $<0.01$ \\
\hline Sabine & -51.31 & 15.51 & -3.3 & $<0.01$ \\
\hline Galveston & -41.22 & 9.04 & -4.6 & $<0.01$ \\
\hline East Matagorda & -0.98 & 9.04 & -0.1 & $>0.10$ \\
\hline Matagorda & -19.40 & 9.04 & -2.1 & 0.03 \\
\hline San Antonio & -22.20 & 9.04 & -2.5 & 0.02 \\
\hline Aransas & -14.15 & 9.04 & -1.6 & $>0.10$ \\
\hline Corpus Christi & -13.68 & 9.04 & -1.5 & $>0.10$ \\
\hline Lower Laguna Madre & -0.54 & 9.04 & -0.1 & $>0.10$ \\
\hline Year $\times$ Galveston & -0.01 & 0.01 & -0.5 & $>0.10$ \\
\hline Year $\times$ East Matagorda & -0.03 & 0.01 & -2.0 & $<0.01$ \\
\hline Year $\times$ Matagorda & -0.02 & 0.01 & -1.7 & 0.08 \\
\hline Year $\times$ San Antonio & -0.01 & 0.01 & -1.6 & $>0.10$ \\
\hline Year $\times$ Aransas & -0.02 & 0.01 & -2.1 & 0.04 \\
\hline Year $\times$ Corpus Christi & -0.02 & 0.01 & -2.1 & 0.04 \\
\hline $\begin{array}{l}\text { Year } \times \text { Lower Laguna } \\
\text { Madre }\end{array}$ & -0.03 & 0.01 & -2.8 & 0.01 \\
\hline
\end{tabular}

and specifically tested in Matagorda Bay, as this bay met Criterion 1 and was considered a potential nursery area. Rate of temporal change was determined by estimating the slope of $\log _{10}$ CPUE trends over time coupled with bootstrapping to obtain CIs for the slope. For Matagorda Bay, the slope ranged between -0.009 and 0.006 (95\% CIs) and indicated temporal population stability within the bay (Table 2A).

\section{Criterion 3 (residency)}

To assess residency patterns of cohorts of YOY bull sharks, we compared size-frequency distributions between spring and fall samples to test the hypothesis that TL of individuals was significantly longer in fall as compared to spring. Mean length $( \pm \mathrm{SD})$ of individuals cap-
Table 2. Carcharhinus leucas. Non-parametric bootstrap with resampling to test the hypothesis that $\log _{10}$ catch-per-uniteffort (CPUE; sharks $\mathrm{h}^{-1}$ ) is not significantly greater than the population mean for (A) young-of-the-year (YOY) and (B) juvenile bull sharks. For each bootstrap iteration, annual mean bull shark CPUE was determined for each bay, and bays with CPUE above the population mean for the entire study period (i.e. satisfying Criterion 1) were coded as ' 1 '; otherwise it was coded as '0.' For YOY sharks, only Matagorda satisfied Criterion 1. For juveniles, San Antonio and Matagorda Bays satisfied Criterion 1. Confidence intervals (CI) for the slope containing or above 0 indicate temporal stability or population increases during the study period (1976 to 2006)

\begin{tabular}{|lrrr|}
\hline Bay & $\mathrm{p}$ & $2.5 \% \mathrm{CI}$ & $97.5 \% \mathrm{CI}$ \\
\hline A Young-of-the-year & & & \\
Sabine & 1.00 & 0.002 & 0.012 \\
Galveston & 1.00 & 0.004 & 0.009 \\
East Matagorda & 1.00 & -0.001 & 0.001 \\
Matagorda & 0.00 & -0.009 & 0.006 \\
San Antonio & 0.34 & 0.000 & 0.007 \\
Aransas & 0.86 & -0.002 & 0.005 \\
Corpus Christi & 1.00 & -0.002 & 0.003 \\
Lower Laguna Madre & 1.00 & -0.003 & 0.002 \\
B Juvenile & & & \\
Sabine & 1.00 & 0.016 & 0.036 \\
Galveston & 1.00 & 0.017 & 0.025 \\
East Matagorda & 1.00 & 0.000 & 0.001 \\
Matagorda & 0.00 & 0.002 & 0.002 \\
San Antonio & 0.02 & 0.005 & 0.018 \\
Aransas & 0.80 & 0.001 & 0.014 \\
Corpus Christi & 1.00 & 0.004 & 0.011 \\
Lower Laguna Madre & 1.00 & -0.004 & 0.003 \\
\hline
\end{tabular}

tured in spring samples $(\mathrm{n}=550)$ was $791 \pm 67 \mathrm{~mm}$ TL, and in fall samples $(n=503) 844 \pm 59 \mathrm{~mm}$ TL. In Matagorda Bay, mean length in spring samples $(\mathrm{n}=233)$ was $794 \pm 86 \mathrm{~mm}$ TL, and in fall samples $(\mathrm{n}=304) 844 \pm$ $59 \mathrm{~mm}$ TL. Size-frequency distributions were similar between sampling periods, although significantly larger in fall samples. This pattern was observed for the entire sample population (all bays pooled, bootstrap test of equality, $\mathrm{p}<0.001$; Fig. 4A) and for Matagorda Bay individually $(p<0.001)$. Moreover, the presence of autocorrelation between sampling years also indicates repeated usage of a nursery habitat. Incorporation of autocorrelation in the error structure significantly improved model performance (log-likelihood test, $\mathrm{p}<0.01$ ).

\section{Juvenile bull sharks}

\section{Criterion 1 (spatial patterns)}

Abundance patterns of juvenile sharks (900 to $1600 \mathrm{~mm}$ TL) were also examined to test the hypothesis that abundance of juvenile bull sharks in a specific bay is greater than the mean abundance in all Texas bays where juveniles occur. Similar to YOY sharks, juvenile bull sharks 

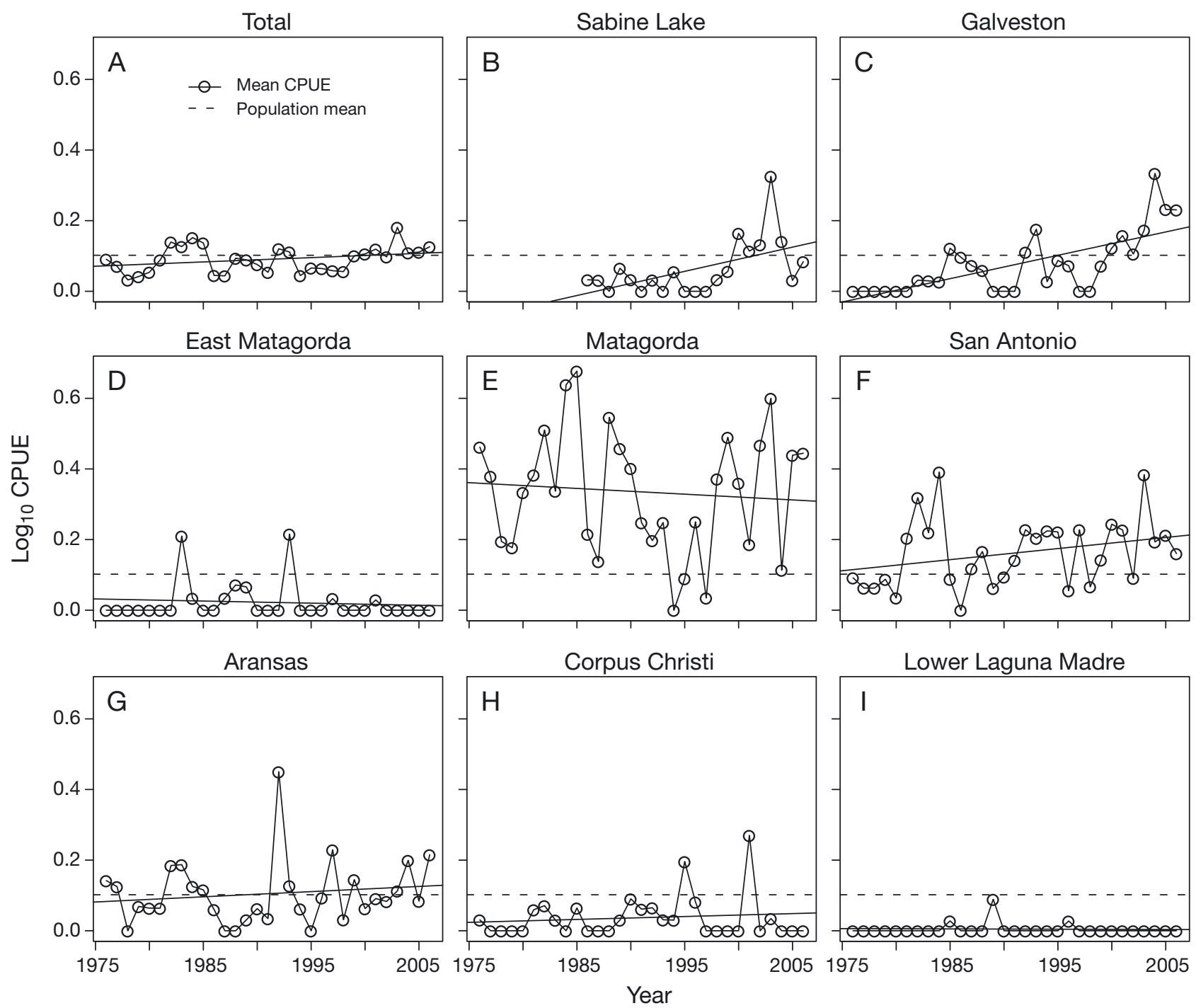

Fig. 3. Carcharhinus leucas. Mean annual young-of-the-year $\log _{10}$ catch-per-unit-effort (CPUE; sharks $\mathrm{h}^{-1}$ ) over time for $(\mathrm{A})$ all bays pooled, and each individual bay (B-I, see Fig. 1), except for Upper Laguna Madre (no bull sharks captured during study period). Least-squares regression line (solid line) and mean population $\log _{10}$ CPUE over the entire study period (dashed line) are indicated

were captured in all major bays except Upper Laguna Madre (Fig. 1). Spatial patterns were tested using leastsquares regression for all 8 bays where sharks were captured (Table 1B). For all bays, mean $\log _{10}$ CPUE was 0.328 (Fig. 2C). Only Matagorda and San Antonio Bays had a mean CPUE significantly above the population mean for the entire study period (bootstrap results, $\mathrm{p}<0.001$; Table 2B), satisfying Criterion 1.

\section{Criterion 2 (temporal patterns)}

The criterion that juvenile sharks use Texas bays repeatedly through time (temporal stability) was also tested. For the entire population, mean CPUE increased significantly throughout the study period $(p<0.01$;
Fig. 5A). Temporal patterns were also investigated for individual bays (Fig. 5B-I) and tested in bays that met Criterion 1 (i.e. Matagorda and San Antonio Bays). Rate of temporal change was determined by estimating the slope of $\log _{10}$ CPUE trends over time coupled with bootstrapping to obtain CIs for the parameter. For Matagorda and San Antonio Bays, $\log _{10}$ CPUE increased significantly over time (Matagorda Bay: 0.002 to 0.002; San Antonio Bay: 0.005 to 0.018) (Table 2B).

\section{Criterion 3 (residency)}

As the size range of juveniles included multiple age classes (age 1 to $10+\mathrm{yr}$ ), it was not possible to detect individual cohorts beyond age 0 . To assess residency 

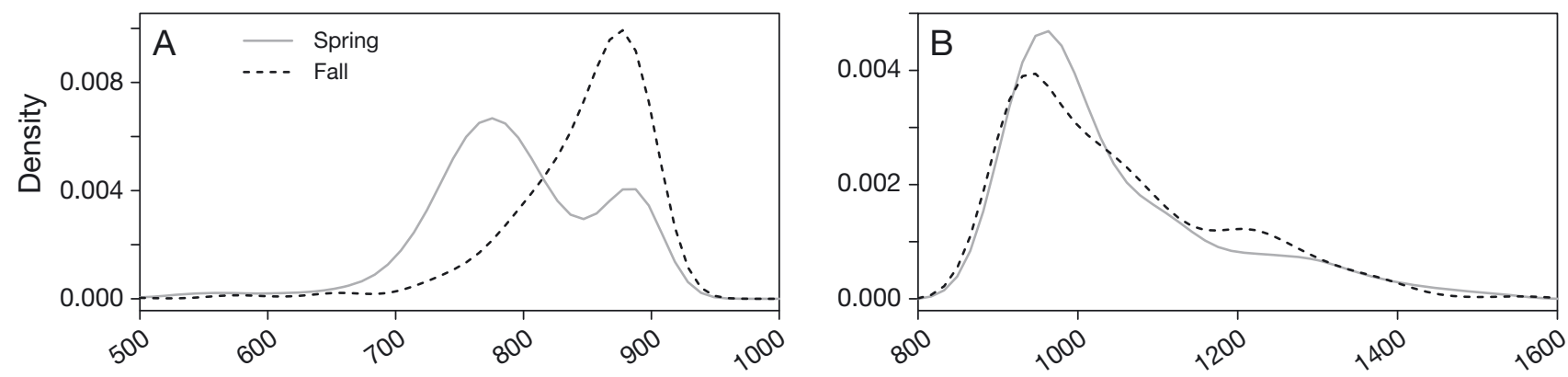

Total length $(\mathrm{mm})$

Fig. 4. Carcharhinus leucas. Length-frequency distributions of (A) young-of-the-year (spring: $\mathrm{n}=550 ;$ fall: $\mathrm{n}=503$ ) and (B) juvenile (spring: $\mathrm{n}=2637$; fall: $\mathrm{n}=1949$ ) bull sharks captured in Texas bays during spring and fall sampling periods between 1976 and 2006
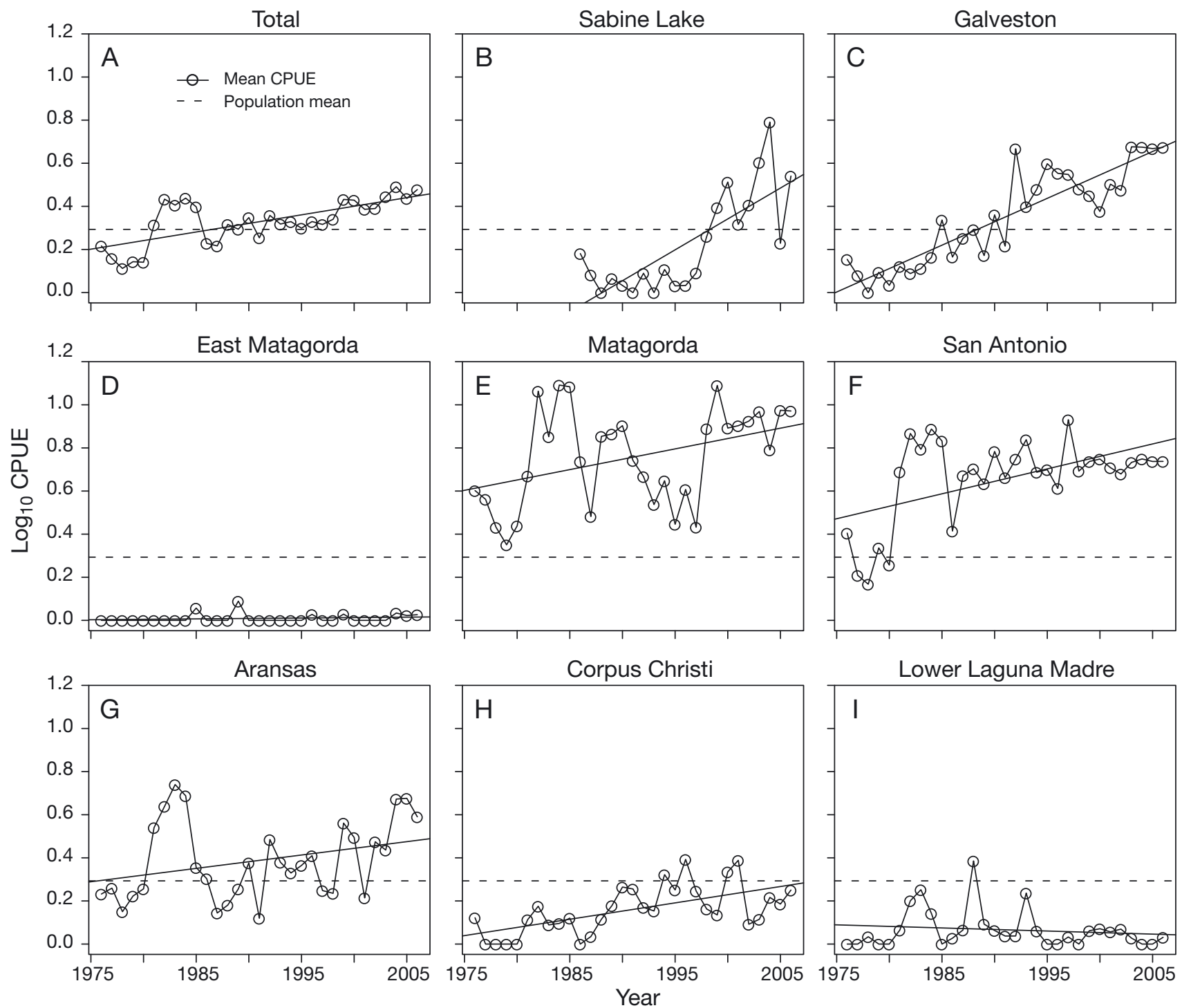

Fig. 5. Carcharhinus leucas. Mean annual juvenile $\log _{10}$ catch-per-unit-effort (CPUE; sharks $\mathrm{h}^{-1}$ ) over time for (A) all bays pooled, and each individual bay (B-I, see Fig. 1), except for Upper Laguna Madre (no bull sharks captured during study period). Leastsquares regression line (solid line) and mean population $\log _{10}$ CPUE over the entire study period (dashed line) are indicated 
patterns of cohorts of juvenile bull sharks, we compared size-frequency distributions between spring and fall samples as well as autocorrelation of $\log _{10}$ CPUE patterns among years to examine residency patterns of juvenile bull sharks. We expected to find similar size patterns between seasons and similar catch rates between adjacent years (significant autocorrelation). Mean length of individuals captured were similar between seasons overall (Fig. 4B) and within Matagorda and San Antonio Bays individually. Overall, mean length of individuals captured in spring sampling $(\mathrm{n}=$ 2637) was $1075 \pm 137 \mathrm{~mm} \mathrm{TL}$, and in fall samples ( $\mathrm{n}=$ 1949) $1058 \pm 140 \mathrm{~mm}$ TL. In Matagorda Bay, mean length in spring samples $(\mathrm{n}=970)$ was $1048 \pm 137 \mathrm{~mm}$ $\mathrm{TL}$, and in fall samples $(\mathrm{n}=697) 1053 \pm 137 \mathrm{~mm}$ TL. In San Antonio Bay, mean length in spring samples $(\mathrm{n}=$ 724) was $1089 \pm 146 \mathrm{~mm} \mathrm{TL}$, and in fall samples $(\mathrm{n}=$ 681) was $1072 \pm 149 \mathrm{~mm}$ TL. Size-frequency distributions were similar between sampling periods, but significantly larger in spring samples. This pattern was observed for the entire sample population (all bays pooled, bootstrap test of equality, p $<0.001$; Fig. 4B) and Matagorda and San Antonio Bays $(\mathrm{p}<0.001)$. Significant autocorrelation was also detected in $\log _{10}$ CPUE patterns between adjacent years, as incorporation of autocorrelation (AR1) in the error structure significantly improved model performance (loglikelihood test, $\mathrm{p}<0.01$ ).

\section{DISCUSSION}

Identification of nursery habitat remains a vital component of marine fisheries management (Bonfil 1997, Beck et al. 2001, Dahlgren et al. 2006, Heupel et al. 2007, McCandless et al. 2007). Using the criteria proposed by Heupel et al. (2007), we provide the first empirical evidence of bull shark estuarine nursery use on the Texas coast, discuss ontogenetic shifts in habitat use patterns, and highlight some limitations in the implementation of the nursery area concept. Of the 9 bay systems considered for YOY nursery habitat, only Matagorda Bay satisfied all 3 criteria. Bull shark abundance in all other bay systems considered was not significantly greater than the mean population abundance (Criterion 1). Abun dance in San Antonio and Aransas Bays were similar to the long-term population mean while abundance in all other bays was typically low. Significant temporal trends were not detected for age 0 bull sharks at the population level (all bays considered) or within Matagorda Bay (the only bay to satisfy Criterion 1 for YOY sharks). Abundance levels in most bays increased during the study period (e.g. Galveston Bay and Sabine Lake). While these bays may not have traditionally served as nursery habitat, these data suggest that they may currently provide nursery functions.

We also tested the nursery hypothesis on juvenile bull sharks (900 to $1600 \mathrm{~mm}$ TL), as a recent review suggests that larger/older juveniles may be most important in sustaining adult shark populations (Kinney \& Simpfendorfer 2009). For juveniles, Matagorda and San Antonio Bays met all 3 nursery habitat criteria. Bull shark abundance in the other bays considered was not significantly greater than mean abundance of all bays. However, temporal patterns were stable or increasing in all bays, and size-at-capture estimates were similar between sampling seasons, suggesting that individual cohorts may stay within the bays for extended periods.

Despite considerable interest in sustaining shark populations, the availability of sampling data with adequate temporal and spatial coverage necessary to characterize nursery habitat using these criteria is rare. Sharks typically occur in low densities and with high temporal and spatial variability in catch records, making quantitative comparisons difficult for short periods or small spatial scales (Froeschke et al. 2010). Few studies simultaneously compare so many systems over such a long period, and the present study provides a unique perspective on shark nursery use. Currently, the estuarine waters along the entire Texas coast are considered bull shark nursery area, including Upper Laguna Madre (McCandless et al. 2002, 2007, Hueter \& Tyminski 2007), although no bull sharks were caught in this lagoon. Few sharks were caught in Lower Laguna Madre and East Matagorda Bay, which are also considered nursery habitat. Our results refine the nursery habitat concept along the Texas coast and suggest that only San Antonio and Matagorda Bays may be providing a nursery function for juvenile sharks according to the criteria proposed by Heupel et al. (2007).

Few studies are able to consider all potential nursery habitats in a species' range in a single study; ours is no exception (Barry et al. 2008, DeAngelis et al. 2008). Using the criteria proposed by Heupel et al. (2007), the number of sites (or habitats) considered and the temporal extent of the study affects nursery designation, because these factors may influence the population mean. For example, consideration of additional study areas with low bull shark abundance would have depressed the population mean, potentially leading to nursery habitat designation for Aransas Bay. This result presents an important limitation of this nursery designation method and demonstrates the need to consider other factors (e.g. food, predator refuge, salinity regime) that may influence habitat use patterns and retain flexibility in the mechanisms used to identify important habitats. Immature bull sharks also occur on 
the open coast in Texas waters and this may also constitute nursery habitat (Hueter \& Tyminski 2007). Unfortunately, the data necessary to test this hypothesis are currently lacking, and abundance estimates between open coast and bay systems are difficult as few gear types are equally effective in both environs.

The present study presents the first quantitative description of shark nursery habitat in Texas waters and one of the first tests of the shark nursery area concept in the Gulf of Mexico. We identified nursery habitat for both YOY and juvenile bull sharks, which may be most important in sustaining adult shark populations (Kinney \& Simpfendorfer 2009). Moreover, CPUE increased significantly for juveniles during the study period, an important consideration given that declines of elasmobranchs have been reported in the Gulf of Mexico (Heithaus et al. 2007). Galveston Bay and Sabine Lake may now provide nursery function as abundance has been above the population mean for the last 10 to $15 \mathrm{yr}$ in each bay system. These findings suggest that nursery use may not be temporally stable and that changes in habitat (Froeschke et al. 2010) or adult stocks may influence nursery use patterns. Continued long-term monitoring may be necessary to detect these changes and evaluate changes in management practices.

Development or maintenance of stable shark populations has proven a difficult task despite considerable interest from fisheries scientists. Life-history traits including slow growth, large size, late maturity, and low fecundity leave them susceptible to overfishing and/or habitat loss (Musick et al. 2000). Additionally, apex predators such as bull sharks provide important ecological roles influencing community structure in systems they inhabit (Heithaus et al. 2008, 2009). Development of testable hypotheses leading to more effective ways of prioritizing areas for conservation and management improves our ability to protect critical habitats (Levin \& Stunz 2005).

Previous researchers have suggested that, along with the need for a greater understanding of nursery habitat, management strategies should include protection of all important age classes and the relative contribution of juveniles from particular nurseries to adult populations should be considered (Beck et al. 2001, Kraus \& Secor 2005). Protection of YOY sharks is primarily based on teleost fisheries management practice, although that may not be the most effective way to manage sharks due to their unique life-history traits (Kinney \& Simpfendorfer 2009). Bull sharks mature late $(15 \mathrm{yr})$ and may use the same nursery areas repeatedly over years (Hueter et al. 2005). Our results support this pattern based on spatial and temporal catch patterns coupled with strong temporal autocorrelation of catch rates between sampling years. How- ever, tracking of individuals may be necessary to demonstrate residency or philopatry (Heupel \& Simpfendorfer 2008, Ortega et al. 2009) and would provide additional insight into movement patterns and habitat use patterns between oceanic and estuarine systems.

Bull shark distribution patterns are strongly affected by environmental conditions in their nursery habitat (Heupel \& Simpfendorfer 2008, Ortega et al. 2009, Froeschke et al. 2010). In Texas bays, distribution patterns of bull sharks are influenced primarily by salinity, temperature, and proximity to tidal inlets (Froeschke et al. 2010). Highest catch rates were predicted in areas characterized by warm temperatures and moderate salinities (10 to 20 ), and proximity to tidal inlets. On the Texas coast, oceanic salinities are buffered with freshwater runoff from major tributaries. Sabine Lake and Galveston Bay typically receive the largest volumes of inflow and consequently have lower salinities $(<10)$ than the southerly Texas bays. However, increased urban demands for freshwater may be altering salinity regimes in the northern bay systems, resulting in higher salinities within the bays and providing more desirable habitat for age 0 bull sharks. Heupel \& Simpfendorfer (2008) suggested that salinity preferences of juvenile bull sharks limit distribution patterns, perhaps as a method to reduce energetic costs of osmoregulation (Marais 1978), permitting more energy for growth. Many Texas bays are in close proximity to major metropolitan centers. Management practices affecting environmental conditions including salinity regimes or access to the Gulf of Mexico through tidal inlets may have dramatic impacts on bull shark populations in the Gulf of Mexico.

This test of nursery value among putative bull shark nurseries demonstrates both the utility and some potential areas where the shark nursery concept could be refined. This method provides a mechanism to compare nursery values to identify the most valuable habitats but may be influenced by different spatial and temporal scales examined. Careful interpretation must be applied to ensure that important areas that do not qualify as nurseries yet still provide important juvenile habitat are incorporated into the management process. For example, Aransas Bay, Galveston Bay, and Sabine Lake support a large number of sharks, and significant increases in bull shark CPUE were detected in both Galveston Bay and Sabine Lake, implying that their importance as nursery habitat may be increasing. An additional consideration is the size of bay systems being considered. For example, CPUE of bull sharks was lower in Galveston compared to Matagorda Bay. However, Galveston Bay is approximately $50 \%$ larger (by surface area) and is likely supporting large numbers of 
juvenile bull sharks, albeit at lower densities than Matagorda Bay. Unfortunately, using the current criteria, there is no framework for incorporating this concept into nursery habitat designation, suggesting that other/additional nursery delineation procedures should be considered. Recent studies on teleosts have used temporal stability of high-density regions to classify nurseries (Fodrie \& Levin 2008). Colloca et al. (2009) identified European hake Merluccius merluccius nurseries using spatio-temporal persistence of abundance data over a 9 yr time period. They found that areas of high density exhibited temporal stability and the most persistent nursery areas $(5 \%$ of total area) included $39 \%$ of total recruitment in the study area. This approach could be extended to other species (Early et al. 2008, Colloca et al. 2009) and may be an efficient method of characterizing shark nurseries where adequate data are available. Moreover, this approach would provide a mechanism for inclusion of areas supporting persistent populations such as Aransas and Galveston Bays in the present study. Finally, this approach incorporates habitat components and could provide insights into natural or anthropogenic-induced changes to shark habitats (Early et al. 2008) and could be extended in systems such as Texas bays where environmental influences on habitat distribution are known (Froeschke et al. 2010). Despite these limitations, the shark nursery area concept provides a much-needed refinement necessary to promote sustainable shark management.

Acknowledgments. Funding for this study was provided by the United States Department of the Interior, US Geological Survey Cooperative Agreement no. 07HQAG0151, The Texas Research Development Fund at Texas A\&M University - Corpus Christi. Gill-net data for sharks was courtesy of Dr. Mark Fisher of the Texas Parks and Wildlife Department, Coastal Fisheries Division. Without their generous cooperation and allowing us access to data, this study would not have been possible. Any use of trade, product, or firm names is for descriptive purposes only and does not imply endorsement by the U.S. Government (e.g. the freeware R).

\section{LITERATURE CITED}

Barry KP, Condrey RE, Driggers WB III, Jones CM (2008) Feeding ecology and growth of neonate and juvenile blacktip sharks Carcharhinus limbatus in the TimbalierTerrebone Bay complex, LA, USA. J Fish Biol 73:650-662

Beck MW, Heck JKL, Able KW, Childers DL and others (2001) The identification, conservation, and management of estuarine and marine nurseries for fish and invertebrates. Bioscience 51:633-641

Bonfil R (1997) Status of shark resources in the Southern Gulf of Mexico and Caribbean: implications for management. Fish Res 29:101-117

Bowman AW, Azzalini A (1997) Applied smoothing techniques for data analysis: the kernel approach with S-Plus illustrations. Oxford University Press, Oxford

Branstetter S, Stiles R (1987) Age and growth estimates of the bull shark, Carcharhinus leucas, from the northern Gulf of Mexico. Environ Biol Fishes 20:169-181

Clark E, von Schmidt K (1965) Sharks of the central Gulf coast of Florida. Bull Mar Sci 15:13-83

> Colloca F, Bartolino V, Lasinio GJ, Maiorano L, Sartor P, Ardizzone G (2009) Identifying fish nurseries using density and persistence measures. Mar Ecol Prog Ser 381: $287-296$

> Dahlgren CP, Kellison CT, Adams AJ, Gillanders BM and others (2006) Marine nurseries and effective juvenile habitats: concepts and applications. Mar Ecol Prog Ser 312: 291-295

> DeAngelis BM, McCandless CT, Kohler NE, Recksiek CW, Skomal GB (2008) First characterization of shark nursery habitat in the United States Virgin Islands: evidence of habitat partitioning by two shark species. Mar Ecol Prog Ser 358:257-271

> Driggers WB III, Ingram GW Jr, Grace MA, Gledhill CT, Henwood TA, Horton CN, Jones CM (2008) Pupping areas and mortality rates of young tiger sharks Galeocerdo cuvier in the western North Atlantic Ocean. Aquat Biol 2:161-170

Early R, Anderson B, Thomas CD (2008) Using habitat distribution models to evaluate large-scale landscape priorities for spatially dynamic species. J Appl Ecol 45:228-238

Efron B, Tibshirani RJ (1993) An introduction to the bootstrap. Chapman \& Hall/CRC, Boca Raton, FL

Fodrie FJ, Levin LA (2008) Linking juvenile habitat utilization to population dynamics of California halibut. Limnol Oceanogr 53:799-812

> Froeschke JT, Stunz GW, Wildhaber MW (2010) Environmental influences on the occurrence of coastal sharks in estuarine waters. Mar Ecol Prog Ser 407:279-292

Heithaus MR, Burkholder D, Hueter RE, Heithaus LI, Pratt HL Jr, Carrier JC (2007) Spatial and temporal variation in shark communities of the lower Florida Keys and evidence for historical population declines. Can J Fish Aquat Sci 64: 1302-1313

Heithaus MR, Frid A, Wirsing AJ, Worm B (2008) Predicting ecological consequences of marine top predator declines. Trends Ecol Evol 23:202-210

Heithaus MR, Delius BK, Wirsing AJ, Dunphy-Daly MM (2009) Physical factors influencing the distribution of a top predator in a subtropical oligotrophic estuary. Limnol Oceanogr 54:472-482

> Heupel MR, Simpfendorfer CA (2008) Movement and distribution of young bull sharks Carcharhinus leucas in a variable estuarine environment. Aquat Biol 1:277-289

> Heupel MR, Carlson JK, Simpfendorfer CA (2007) Shark nursery areas: concepts, definition, characterization and assumptions. Mar Ecol Prog Ser 337:287-297

Hueter RE, Tyminski JP (2007) Species-specific distribution and habitat characteristics of shark nurseries in Gulf of Mexico waters off Peninsular Florida and Texas. Am Fish Soc Symp 50:193-223

Hueter RE, Heupel MR, Heist EJ, Keeney DB (2005) Evidence of philopatry in sharks and implications for the management of shark fisheries. J Northwest Atl Fish Sci 35: $239-247$

> Kinney MJ, Simpfendorfer CA (2009) Reassessing the value of nursery areas to shark conservation and management. Conserv Lett 2:53-60

> Kraus RT, Secor DH (2005) Application of the nursery-role hypothesis to an estuarine fish. Mar Ecol Prog Ser 291: 301-305

Levin PS, Stunz GW (2005) Habitat triage for exploited fishes: 
Can we identify essential 'Essential Fish Habitat?' Estuar Coast Shelf Sci 64:70-78

Marais JFK (1978) Routine oxygen consumption of Mugil cephalus, Liza dumerili and L. richardsoni at different temperatures and salinities. Mar Biol 50:9-16

Martinez-Andrade F, Fisher M, Bowling B, Balboa B (2009) Marine resource monitoring operations manual. Texas Parks and Wildlife Department Coastal Fisheries Division, Austin, TX

McCandless CT, Pratt HL Jr, Kohler NE (eds) (2002) Shark nursery grounds of the Gulf of Mexico and east coast waters of the United States: an overview. An internal report to NOAA's Highly Migratory Species Office. NOAA Fisheries, Narragansett, RI

McCandless T, Kohler NE, Pratt HL Jr (2007) Species specific shark nursery habitat summary tables. Am Fish Soc Symp 50:365-390

Musick JA, Burgess G, Cailliet G, Camhi M, Fordham S (2000) Management of sharks and their relatives (Elasmobranchii). Fisheries (Bethesda) 25:9-13

Neer JA, Thompson BA, Carlson JK (2005) Age and growth of Carcharhinus leucas in the northern Gulf of Mexico: incorporating variability in size at birth. J Fish Biol 67:370-383

Neer JA, Blackburn JK, Thompson BA (2007) Shark nursery areas of central Lousiana's nearshore coastal waters. Am Fish Soc Symp 50:317-330

> Ortega L, Heupel M, Beynen P, Motta P (2009) Movement patterns and water quality preferences of juvenile bull sharks (Carcharhinus leucas) in a Florida estuary. Environ

Editorial responsibility: Benjamin Ruttenberg,

Palmetto Bay, Florida, USA
Biol Fishes 84:361-373

Parsons GR, Hoffmayer ER (2007) Identification and characterization of shark nursery grounds along the Mississippi and Alabama Gulf Coasts. Am Fish Soc Symp 50:301-316

Pinheiro J, Bates D, DebRoy S, Sarkar D, R Core team (2008) nlme: linear and nonlinear mixed effects models. R package version 3.1-89, www.citeulike.org/user/schulman/ article/3406976

> Pondella DJ II, Froeschke JT, Wetmore LS, Miller E, Valle CF, Medeiros L (2008) Demographic parameters of yellowfin croaker, Umbrina roncador (Perciformes: Sciaenidae), from the Southern California Bight. Pac Sci 62:555-568

R Development Core Team (2008). R: a language and environment for statistical computing. R Foundation for Statistical Computing, Vienna www.R-project.org

- Reese MM, Stunz GW, Bushon AM (2008) Recruitment of estuarine-dependent nekton through a new tidal inlet: the opening of Packery Channel in Corpus Christi, TX, USA. Estuar Coast 31:1143-1157

> Simpfendorfer C, Freitas G, Wiley T, Heupel M (2005) Distribution and habitat partitioning of immature bull sharks (Carcharhinus leucas) in a Southwest Florida estuary. Estuar Coast 28:78-85

Stunz GW, Minello TJ, Rozas L (2010) Relative value of oyster reef as habitat for estuarine nekton in Galveston Bay, Texas. Mar Ecol Prog Ser 406:147-159

> Wood SN (2008) Fast stable direct fitting and smoothness selection for generalized additive models. J R Stat Soc B 70:495-518

Submitted: April 19, 2010; Accepted: September 7, 2010 Proofs received from author(s): November 1, 2010 